高齢者非小細胞肺癌手術症例の臨床的検討

\author{
中川達雄 1 - 奥村典仁 1 . 三好健太郎 1 ・ \\ 張 性洙2 ・松岡智章 1 亀山耕太郎 1
}

要旨一一目的 . 75 歳以上高齢者肺癌の臨床的側面を明らかにすること. 方法. 1982 年 4 月から 1999 年 12 月迄に根 治目的に手術を施行した高齢者 102 例を含む非小細胞肺癌 726 例の検討を行った . 結果 . 非高齢者群に比べ高齢者群 では，縮小手術の割合が多く( $3.5 \%$ vs $9.8 \% ; p<0.01) ， N D 2$ 以上郭清の割合が少なかった $(91.5 \%$ vs $79.4 \% ; p<0.01)$. 病理病期ではIII 期の割合が少なく $(23.2 \%$ vs $12.7 \%$; p < 0.05) , 術後補助療法の割合が少なかった $(27.1 \%$ vs $11.8 \%$; $\mathrm{p}<0.05)$. 高齢者群で術前合併症は $57.8 \%$ ，術後合併症は $40.2 \%$ に認め，手術関連死は $3.9 \%$ で, 非高齢者群 $1.3 \%$ に 比べ多い傾向であった $(p<0.1) .5$ 年生存率はI期で $69.6 \%$ と良好であったが, 非高齢者群に比べ劣っていた $(p<$ 0.05). 死因では他病死の割合が। 期で $60.0 \%$ と高かった $(p<0.05)$. 予後因子解析では, 病理病期のみが単変量および 多変量解析で有意であった . 結論 . 高齢者群では他病死の割合が多いが, おおむね非高龄者群と同等の予後が得られ， 手術は高齢者肺癌において有効な治療法と考えられた . (肺癌 . 2005;45:697-703)

索引用語一一高齢者, 非小細胞肺癌，手術，予後，合併症

\title{
Clinical Assessment of Surgical Treatment for E Iderly Patients With Non-small Cell Cancer
}

\author{
Tatsuo Nakagawa1; Nori hi to Okumura1; Kentaro Mi yoshi 1; \\ Sung-Soo Chang; Tomoaki Matsuoka1; Kotaro Kameyama1
}

\begin{abstract}
AB STRACT — Objective. This study investigated the clinical aspects of surgically treated elderly patients with nonsmall cell lung cancer (NSCLC). Methods. A total of 726 patients including 102 elderly patients 75 or more years of age, who underwent surgery for NSCLC between April 1982 and December 1999 were retrospectively evaluated. Results. The percentage of patients who underwent limited operations or lymph node dissection of level 1 or less was significantly higher among elderly patients than among younger patients ( $3.5 \%$ vs $9.8 \% ; p<0.01,8.5 \%$ vs $20.6 \% ; p<0.01$, respectively). The ratios of patients with pathological stage III disease was significantly lower among elderly patients than among younger patients $(23.2 \%$ vs $12.7 \% ; p<0.05)$. Postoperative adjuvant therapies were perfomed for a lower percentage of elderly patients than younger patients $(27.1 \%$ vs $11.8 \% ; p<0.05)$. Preoperative and postoperative complications occurred in $57.8 \%$ and $40.2 \%$ of the elderly patients, respectively. The surgical mortality rate was $3.9 \%$ among elderly patients and $1.3 \%$ among younger patients, with only a marginal difference. The ratio of non-cancer related death was higher among elderly patients than among younger patients, especially in pathological stage I $(27.0 \%$ vs $60.0 \% ; p<$ 0.05 ). The 5-year survival rate of the elderly patients with pathological stage I disease was $69.6 \%$ and significantly worse than that of younger patients in the same stage. The analysis of prognostic factors in the elderly group demonstrated that the pathological stage was the only significant factor on both univariate and multivariate analysis. Conclusion. The prognosis of elderly patients was acceptable whereas the percentage of non-cancer-related death was higher.
\end{abstract}

\footnotetext{
1倉敷中央病院呼吸器外科; 2香川大学医学部第 2 外科.

別刷請求先 : 中川達雄, 倉敷中央病院呼吸器外科, $\overline{7} 710-8602$

岡山県倉敷市美和 1-1-1(e-mail: tn8336@kchnet.or.jp) .

1Department of Thoracic Surgery, Kurashiki Central Hospital, Japan; 2Second Department of Surgery, Faculty of Medicine, Kagawa University, J apan.
}

Reprints: Tatsuo Nakagawa, Department of Thoracic Surgery, 11-1 Miwa, Kurashiki-shi, Okayama 710-8602, Japan.(e-mail: tn8336@ kchnet.or.jp).

Received April 28, 2005; accepted J une 28, 2005.

(C) 2005 The J apan Lung Cancer Society 
Surgical treatment was considered an effective therapeutic method even in elderly patients. (J LC. 2005;45:697-703) KE Y WORDS — Elderly patients, Non-small cell lung cancer, Surgery, Prognosis, Complication

はじめに

人口の高齢化と肺癌の増加に伴い，高齢者肺癌患者に 対する治療の適正な選択を迫られる機会が増えている． 肺癌治療において手術療法は根治性の点で重要な治療法 と考えられるが，高齢者は耐術能が低下しており，周術 期の合併症が増加することが予測される．高齢者に対し て手術を施行すべきか否かについては異論のあるところ であるが，高齢者といっても加齢に伴う身体的・精神的 変化には個体差があり，年齢でのみ治療方法を層別化す るのは合理的でない，高齢者肺癌切除症例の臨床的側面 を明らかにする目的で, 当施設における高齢者肺癌の手 術成績，術後合併症等につき検討を行ったので報告する．

\section{対象と方法}

1982 年 4 月から 1999 年 12 月までに当施設で根治を 目的に手術を施行した非小細胞肺癌のうち, 病理病期が 確定しているもので低悪性度腫瘍を除く 727 例を対象と し，後ろ向きに検討を行った.75 歳未満 (以下非高齢者 群) は 624 例，75 歳以上 (以下高齢者群) は 102 例，高 齢者群の中で 80 歳以上(以下超高齢者群)は 15 例であつ た . 病理組織分類および術後病理病期は「日本肺癌学会 の肺癌取り扱い規約 (第6 版) 」に従い決定した . 手術死 亡は術後 30 日以内の死亡とし, 在院死亡は退院すること なく術後 31 日以後に死亡したものと定義した .2 群間の 比較はt検定および $\chi$ 二乗検定を用い, 生存曲線は Kaplan-M eier 法で算出し,log-rank 検定で比較を行い, 多 変量解析は Cox 比例ハザードモデルを用いた. 統計学的 有意差は $p<0.05$ をもって有意とした .

結 果

患者背景 (T able 1)

高齢者群は計 102 例（男 69 例，女 33 例）であり，全 体に占める割合は $14.0 \%$ (男 $14.3 \%$ ，女 $13.6 \% ; p>0.1$ ) であり，このうち超高齢者群は 15 例で全体の $2.1 \%$ で あった .全期間を前期(1982〜1987 年)，中期(1988〜1993 年)，後期（1994１999 年）に区分すると，光れ光れ $11.4 \%, 12.7 \%, 15.9 \%$ を占め,増加傾向がみられた(data not shown).

組織型は腺癌 59 例 $(57.8 \%)$, 扁平上皮癌 38 例 (37.3\%) であり, 非高齢者群と分布に有意差を認めなかった $(p>$ 0.1 ). 縮小手術 (肺葉以下の切除) は高齢者群で 10 例 $(9.8 \%)$ に行われており, 非高齢者群の 22 例 $(3.5 \%)$ に
比へ有意に多かった $(p<0.01)$. リンパ節郭清は 81 例 $(79.4 \%)$ で 2 群以上の郭清が行われており，非高齢者群 の 571 例 $(91.5 \%)$ に比へ有意に低かった $(p<0.01)$. 術 後補助療法は, 高齢者群で 12 例 $(11.8 \%)$ に施行されて おり，非高齢者群の 169 例 $(27.1 \%)$ に比へ有意に少な かった $(p<0.01)$. 術後補助療法の内訳は, 化学療法が 98 例 (高齢者 3 例)，放射線治療 68 例 (高齢者 9 例)，放 射線化学療法 15 例 (高齢者なし) であつた . 術後病期の 割合は, 高齢者群で川I 期が 13 例 (12.7\%) に対し非高齢 者群で 145 例 $(23.2 \%)$ であり, 高齢者群で有意にIII 期の割合が少なかった $(p<0.05)$.

病理病期別予後 (T able 2)

術後 5 年生存率は高齢者群 , 非高齢者群の全体で光れ ぞれ $58.9 \% ， 65.4 \%$ であり，有意差を認めなかった ( p > 0.1 ) . 超高齢者群の術後 5 年生存率は $70.6 \%$ であり, 非 高齢者群および超高齢者を除く高齢者群と比へ有意差を 認めなかった $(p>0.1)$. 病期別 5 年生存率は高齢者群で I，II，III，IV 期の順に乥れ光れ 69.6\% ( $n=63), 59.3 \%$ $(n=21), 15.3 \%(n=13), 20.0 \%(n=5)$ であり, 非高 齢者群で光れ光れ $81.7 \%(n=368), 51.6 \%(n=90)$, $34.4 \%(n=145), 42.9 \%(n=21)$ であった . 病期別に予 後を比較すると। 期において高齢者群の予後が有意に不 良であった $(\mathrm{p}<0.05)$. IA，IB 期で別々に比較すると， IA 期の 5 年生存率は高齡者群で $75.9 \%(n=42)$ と良好で あったが非高齢者の $88.8 \%(n=213)$ に比べて統計学的 に有意に劣っていた $(p<0.01)$.

術後死因 ( F igure 1)

102 例中 41 例 $(40.2 \%)$ で術後死亡が確認されたが， 原病死によるものが 22 例 $(53.7 \%$ ), 他病死によるものが 16 例 $(39 \%)$ ，不明が 3 例 $(7.3 \%)$ であった . 病期別の 死因では高齢者群において他病死が占める割合はI 期で $60.0 \%$ と高く, 非高齡者群に比べ有意差を認めた $(p<$ 0.05) . II 期以降の病期では, 両群ともに原病死の割合が 多く有意差は認めなかった .

術前合併症 (T able 3)

術前合併症は 59 例 (57.8\%) で認め，このうち超高齢 者は 8 例 $(53.3 \%)$ であった. 主な合併症は高血圧症 21 例 $(20.6 \%)$ ，糖尿病 13 例 $(12.7 \%)$ ，虚血性心疾患 8 例 $(7.8 \%)$, 不整脈 7 例 $(6.9 \%)$, COPD 6 例 $(5.9 \%)$, 肝機 能障害 3 例 (2.9\%), 腎機能障害 3 例 (2.9\%) であった . 術後合併症 (T able 4)

術後合併症は 41 例 $(40.2 \%)$ に認め，このうち超高齢 者群は 5 例 ( $33.3 \%$ ) であった . 術後合併症の発生率は非 
Table 1. Patient's Background

\begin{tabular}{|c|c|c|c|}
\hline Factors & $\begin{array}{l}\text { Non-E Iderly } \\
(\mathrm{n}=624)\end{array}$ & $\begin{array}{c}\text { Elderly } \\
(\mathrm{n}=102)\end{array}$ & $\mathrm{p}$-value \\
\hline \multicolumn{4}{|l|}{ Sex } \\
\hline Male & 415 & 69 & \multirow[t]{2}{*}{$0.1<$} \\
\hline Female & 209 & 33 & \\
\hline \multicolumn{4}{|l|}{ Operation } \\
\hline Pneumonectomy & 56 & 7 & \multirow[t]{3}{*}{$<0.05$} \\
\hline Lobectomy & 546 & 85 & \\
\hline Limited Resection & 22 & 10 & \\
\hline \multicolumn{4}{|c|}{ Lymph Node Dissection } \\
\hline ND0-1 & 53 & 21 & \multirow{2}{*}{$<0.01$} \\
\hline ND2 $\leqq$ & 571 & 81 & \\
\hline \multicolumn{4}{|c|}{ Radicality of Resection } \\
\hline Complete & 572 & 95 & \multirow[t]{2}{*}{$0.1<$} \\
\hline Incomplete & 52 & 7 & \\
\hline \multicolumn{4}{|l|}{ Preoperative Therapy } \\
\hline Yes & 33 & 2 & \multirow[t]{2}{*}{$0.1<$} \\
\hline No & 591 & 100 & \\
\hline \multicolumn{4}{|c|}{ Postoperative Therapy } \\
\hline Yes & 169 & 12 & \multirow[t]{2}{*}{$<0.01$} \\
\hline No & 455 & 90 & \\
\hline \multicolumn{4}{|l|}{ Pathologic Type } \\
\hline Adeno. & 395 & 59 & \multirow{5}{*}{$0.1<$} \\
\hline Sq.c.c & 196 & 38 & \\
\hline Large & 11 & 1 & \\
\hline Adsq & 19 & 4 & \\
\hline Others & 3 & 0 & \\
\hline \multicolumn{4}{|l|}{ p-Stage } \\
\hline I & 368 & 63 & \multirow{4}{*}{$<0.1$} \\
\hline II & 90 & 21 & \\
\hline$\| I I^{*}$ & 145 & 13 & \\
\hline IV & 21 & 5 & \\
\hline
\end{tabular}

Table 2. 5-year Survival Rate Stratified According to Pathologic Stage

\begin{tabular}{llll}
\hline \multirow{2}{*}{ p-Stage } & \multicolumn{2}{c}{ 5-year survival rate $(\%)$} & p-value \\
& \multicolumn{1}{c}{ Non-Elderly } & \multicolumn{1}{c}{ Elderly } & \\
\hline Total & $65.4 \%(n=624)$ & $58.9 \%(n=102)$ & $0.1<$ \\
I & $81.7 \%(n=368)$ & $69.6 \%(n=63)$ & $<0.05$ \\
II & $51.6 \%(n=90)$ & $59.3 \%(n=21)$ & $0.1<$ \\
III & $34.4 \%(n=145)$ & $15.3 \%(n=13)$ & $0.1<$ \\
IV & $42.9 \%(n=21)$ & $20.0 \%(n=5)$ & $0.1<$ \\
I A & $88.8 \%(n=213)$ & $75.9 \%(n=42)$ & $<0.01$ \\
I B & $71.5 \%(n=155)$ & $55.5 \%(n=21)$ & $0.1<$ \\
\hline
\end{tabular}

高齢者群の 199 例 (31.9\%) に比べ多い傾向を認めた $(\mathrm{p}=$ 0.098).

主な合併症は呼吸器合併症 31 例 $(30.4 \%)$, 心合併症 11 例 (10.8\%) であり，呼吸器合併症では肺瘻 (10日を 超えるドレナージ期間を要した症例) 12 例 (11.8\%)，排
液過多 (10日を超えるドレナージを要した症例)9 例 $(8.8 \%)$, 肺炎・膿胸 6 例 $(5.9 \%)$, 無気肺・呼吸不全 3 例 $(2.9 \%)$ であった . 術後せん妄は 5 例 $(4.9 \%)$ にみら れた . 術後合併症と他の臨床因子との間に有意な相関は 認めなかった . 手術死亡もしくは在院死亡は 4 例 (3.9\%) 
stage I

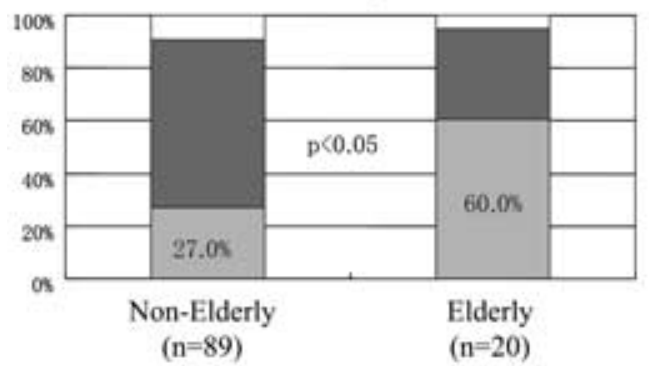

stage III

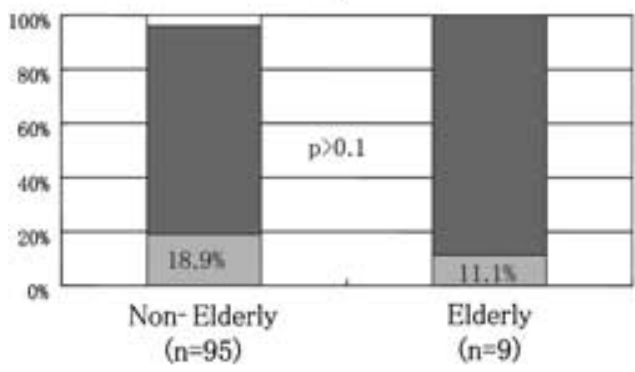

stage II

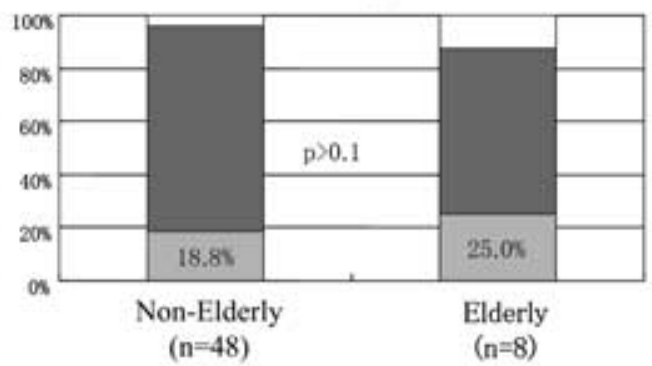

stage IV

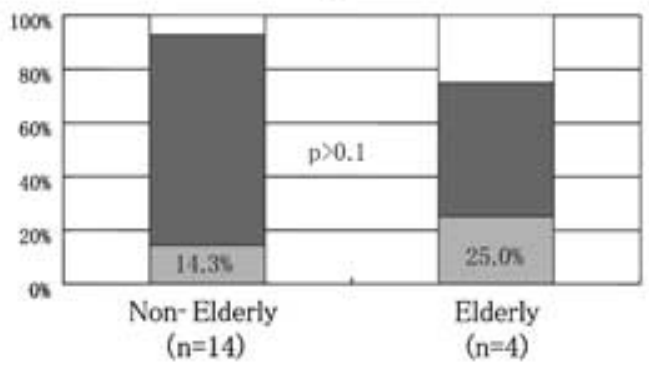

Figure 1. Cause of postoperative death.

Table 3. Preoperative Complications

\begin{tabular}{lcc}
\hline & $\begin{array}{c}\text { Number } \\
\text { (octogenarian) }\end{array}$ & Percentage \\
\hline Preoperative Complications & $59(8)$ & $57.8 \%$ \\
Hypertension & $21(2)$ & $20.6 \%$ \\
Diabetes Mellitus & $13(0)$ & $12.7 \%$ \\
Ischemic Heart Disease & $8(3)$ & $7.8 \%$ \\
Arrhythmia & $7(3)$ & $6.9 \%$ \\
COPD & $6(0)$ & $5.9 \%$ \\
Liver Dysfunction & $3(0)$ & $2.9 \%$ \\
Renal Dysfunction & $3(0)$ & $2.9 \%$ \\
Others & $18(4)$ & $17.6 \%$ \\
\hline
\end{tabular}

であり，非高齢者群 8 例 $(1.3 \%)$ と比べ多い傾向を認め た $(\mathrm{p}<0.1)$.

予後因子解析 (T able 5)

高齢者群の予後因子を検討する目的で, 12 の臨床因子 (年齢，性別，PS，術式(縮小手術 vs 非縮小手術)，リン 八唧郭清範囲, 手術根治度, 術前治療の有無, 術後治療 の有無, 病理組織, 病理病期, 術前合併症の有無, 術後 合併症の有無) 別に単変量解析を行った結果, PS, 手術 根治度, 術後補助療法の有無, 病理病期で予後に有意差 を認めた .更に上記 12 因子を用いて多変量解析を行った 結果, 病理病期のみが独立した予後因子であることが判 明した。

\section{考 察}

2001 年の人口動態統計資料によると日本人の平均寿 命は男性で 78.07 歳，女性で 84.93 歳であり，高齢化は 年々進んでいる .また, 悪性新生物による死亡の割合は 30 歳以降急激に増加し, 高齢者において悪性新生物は主 たる死亡原因となっている . 悪性新生物の中でも肺癌に よる死亡は男性で $22.0 \%$,女性で $12.7 \%$ と多くを占めて おり，乥れ光れ死亡原因の第 1 位，第 2 位となっている . このような社会背景にあって高齡者肺癌人口は今後ます ます増加することが予測される . 今回の検討でも肺癌手 術症例に占める高齢者の割合が経時的に増加傾向にある ことがわかるが, 平均寿命の延長や胸腔鏡を用いた低侵 襲手術の普及に伴い, 高齢者肺癌の手術の割合や耐術年 齢が更に高くなることが予想される . 当施設においても 最近 2 年間の集計では 75 歳以上高齢者肺癌の手術の割 合は $22.7 \%, 80$ 歳以上では $5.9 \%$ と著しく増加しており， 侵襲が高い一方で根治性が期待できる外科治療の適応に 関し, 治療成績および合併症の面から充分な検討がなさ れる必要がある.

高齢者の定義については確固としたものはないが , 従 来 75 歳以上を対象とした報告1-6 が多くみられ，最近で は 80 歳以上を超高齢者とする報告7,8 が増えてきてい る. 今回の検討では 80 歳以上の超高齢者群と 80 歳未満 の高齢者群では予後に有意な差が認められなかったこ と,また,80 歳以上の超高齢者肺癌患者は全体の 15 例と 
Table 4. Postoperative Complications

\begin{tabular}{lcc}
\hline & $\begin{array}{c}\text { Number } \\
\text { (octogenarian) }\end{array}$ & Percentage \\
\hline Post-Operative Complications & $41(5)$ & $40.2 \%$ \\
Cardiac Events & $11(2)$ & $10.8 \%$ \\
$\quad$ Arrhythmia & $10(0)$ & $9.8 \%$ \\
Pulmonary Events & $31(3)$ & $30.4 \%$ \\
Pleural Fistula * & $12(1)$ & $11.8 \%$ \\
Pulmonary Infection (Pneumonia, Empyema) & $6(0)$ & $5.9 \%$ \\
Excessive Pleural Effusion & $9(2)$ & $8.8 \%$ \\
Atelectasis or Respiratory Failure & $3(0)$ & $2.9 \%$ \\
Other Events & $11(1)$ & $10.8 \%$ \\
Delirium & $5(0)$ & $4.9 \%$ \\
Surgical mortality $\dagger$ & $4(0)$ & $3.9 \%$ \\
\hline
\end{tabular}

Table 5. Prognostic Analysis

\begin{tabular}{|c|c|c|c|c|c|c|}
\hline \multirow[b]{2}{*}{ Factors } & \multicolumn{3}{|c|}{ Univariate analysis } & \multicolumn{3}{|c|}{ Multivariate analysis } \\
\hline & Number & $\begin{array}{c}5 \text {-year } \\
\text { survival rate }\end{array}$ & $p$-value & $\mathrm{HR}$ & $95 \% \mathrm{Cl}$ & $p$-value \\
\hline \multicolumn{7}{|l|}{ PS } \\
\hline 0 & 72 & 52.5 & $<0.01$ & 0.932 & $0.446-1.950$ & $0.1<$ \\
\hline 1 & 28 & 77.8 & & & & \\
\hline $2 \leqq$ & 2 & 0 & & & & \\
\hline \multicolumn{7}{|c|}{ Radicality of Resection } \\
\hline Complete & 95 & 61.2 & $<0.05$ & 1.167 & $0.270-5.045$ & $0.1<$ \\
\hline Incomplete & 7 & 22.2 & & & & \\
\hline \multicolumn{7}{|c|}{ Postoperative Therapy } \\
\hline No & 90 & 62.5 & $<0.01$ & 1.978 & $0.693-5.645$ & $0.1<$ \\
\hline Yes & 12 & 29.1 & & & & \\
\hline \multicolumn{7}{|l|}{ p-Stage } \\
\hline 1 & 63 & 69.6 & $<0.01$ & 1.603 & $1.029-2.499$ & $<0.05$ \\
\hline II & 21 & 59.3 & & & & \\
\hline III & 13 & 15.3 & & & & \\
\hline IV & 5 & 20 & & & & \\
\hline
\end{tabular}

少なく ,高齢者肺癌の特徵を検討するために 75 歳以上を もって高齢者と定義し比較検討を行った．

今回の検討より高齢者肺癌の特徵と思われる患者背景 は，1) 縮小手術の割合が多く，2 群リンパ節郭清の比率 が低いこと，2)術後補助療法の施行率が低いこと，3)病 理病期 III 期の比率が低いこと，4)I期の予後は良好であ るが, 非高齢者群に劣ること，5）！期に占める他病死の 多いこと，であった . 以下, これらの点について考察を 行う.

術式に関しては, リンパ節郭清を含めた肺葉切除を標 準とすべきという報告2,9-11 がある一方，部分切除や区域 切除などの縮小手術を積極的に考慮してよいとの報告も ある .4,12,13 我々の検討では術式により予後に有意差は認
めなかったが, 術式の決定は病巣の部位, 進行度, 呼吸 機能等を考慮した耐術能により決定されるため，一概に 年齢で術式を決定することはできない.Ishida14 らは肺 葉切除および全摘術が可能である指標として, 術後予測 VC/体表面積 $\left(\mathrm{I} / \mathrm{m}^{2}\right)$ および予測 FEV 1.0 体表面積 $\left(\mathrm{I} / \mathrm{m}^{2}\right)$ がそれぞれ $0.8 ， 0.6$ 以上あることとしている.当施設で は, 術前に原則全例に負荷心電図を行い潜在的心疾患の 評価を行うと同時に, 予測 FEV 1.0 指数 $\left(\mathrm{I} / \mathrm{m}^{2}\right)$ が 0.8 以上あれば肺葉切除を原則とし，0.8〜0.6では poor risk 群とし，区域切除等の縮小手術も考慮している.また 0.6 以下では原則として手術療法は選択しない方針としてい る . 高齡者においても肺切除の適応は原則的に同じであ るが, 耐術能の低下が予想されるため, 術前合併症の有 
無やPSなど総合的に判断し術式をより慎重に選択する 必要があると考える.

術後補助療法としての放射線療法, 化学療法は, 現時 点で標準治療として行うように勧めるだけの根拠が確立 されていない.15 毒性の強い補助療法は, 手術により低下 した全身状態を更に悪化させることが色惧され，高齢者 においては積極的に行うことは困難である.当施設では， 従来高齢者を避け,ECOG の PS 0 もしくは 1 程度の全身 状態が良好な症例を補助療法の対象とすることが多く, 今回の検討でも高齢者群の術後補助療法の施行率は, 非 高齢者群に比へ有意に低く，逆に術後補助療法を行った 群は予後が不良であった。また，術後病期別の補助療法 施行率は，I，II，III，IV 期で光れ光れ，7.2\%，32.4\%， $65.8 \% ， 38.5 \%$ であり，II 期またはIII 期以上の進行癌が 補助療法の対象となることが多かった。近年, 術後補助 化学療法の有効性を示す報告がみられるようになり，特 に比較的早期の症例での有効性が報告されている． ${ }^{16,17}$ また，分割投与など投与方法の工夫により副作用の軽減 が図られるようにもなってきた . 高齡者肺癌に対する補 助療法の位置づけは, 今後変わりゆく可能性があるが, 暦年齢の高さのみで補助療法を制限するのではなく，全 身状態に充分配慮した上で高齢者肺癌症例にも治療を考 慮することが重要と考えられる．

今回の結果では, 高齢者群の予後は非高齢者群に比べ おおむね同等であった.1期における 5 年生存率は $69.6 \%$ と比較的良好であり，特にIA 期においては $75.9 \%$ と良好であり，諸家の報告1,4-6に比べ劣るものではな かった . この結果は, 高齢者肺癌においても早期におけ る外科療法は有効な治療方法であることを示すものであ る.しかしながら病期別に比較すると，I 期における予後 は, 非高齢者群に比へ統計学的に劣る結果であった . こ の要因としては, 第 1 には高齢者群で縮小手術の割合が 多く,2 群以上のリンパ節郭清を行った割合が低いため, I 期の中にリンパ節転移を伴う進行癌が潜在的に含まれ ていた可能性が考えられる .このことは高齢者群で川 期の割合が有意に低いことの一因とも考えられる．第 2 には，死因に占める他病死の割合が। 期で有意に高いニ とである .これは高齢者肺癌の特徵を示すものであり， 比較的予後の良い早期の癌では, 原疾患を克服しても他 疾患や生物学的寿命などで死亡する割合が多くなり，। 期の術後の予後を低下させているものと思われる .

術前合併症の併存率は諸家の報告では 42.9 84.5\% 3-5 であり，今回の検討では 59 例 $(57.8 \%)$ に術前合併症が みられた。他の報告と同樣に，高血圧症や不整脈，虚血 性心疾患などの心疾患の合併が多く，次いで糖尿病や COPD などの合併が多くみられた . これらの疾患は高齢 者に多い common disease であり，高齢者肺癌の治療を
行う際，充分に念頭におきながら術前評価を行うことが 重要であると思われる.一方, 術後合併症は 41 例 (40.2％) にみられた . 術後合併症の定義は諸施設により 異なり，諸家の報告でも 33.3〜 65.6\% 1 1-5 と開きがあった が , 今回の検討では, 術後合併症の定義を「術後に発生 した何らかの治療を要する病態」と定義し, 術後の遷延 性リークや排液過多は 10 日を超えるドレナージ期間を 要したものを合併症と定義した . 内訳は心合併症, 呼吸 器合併症が多く，致死的な合併症につながる可能性があ るため, 術前合併症のコントロール，術前からの排痰訓 練と禁煙の徹底, 充分な術後疼痛コントロール, 早期離 床の推進等が重要と思われる . また, 近年普及している 胸腔鏡を用いた手術は，手術侵襲を軽減し周術期合併症 の発生を低下させる可能性がある .Koizumi ら ${ }^{18}$ は,肺葉 切除を施行した高齢者肺癌患者において, 胸腔鏡下手術 は開胸術に比べ呼吸機能の低下が少なく, 術後呼吸器合 併症の発生率が有意に低かったと報告している．当施設 では,2001 年より原発性肺癌に対する胸腔鏡下手術を本 格導入しており，対象症例中で胸腔鏡下手術を施行した ものは僅かであり, 本研究からは術後合併症に対する胸 腔鏡下手術の有用性は論ずることはできない .

\section{結 論}

高龄者群の術後予後について，因子別解析をおこなつ たところ単変量解析および多変量解析で有意差を認めた のは病理病期であった . このことは, 高齢者肺癌といえ ど病理病期が最も予後に影響を与えることを示すもので あり, この意味においては, 高齢者肺癌といっても決し て特異な症例群でないと思われる. 術前に呼吸, 循環器 系を含む全身状態の評価を充分に行った上で適応を決定 し，周術期の管理を慎重に行うならば，手術療法は，特 に早期の高齢者肺癌における有効な治療法であると考え られる。

\section{REFERENCES}

1. 中村広繁 鈴木喜雅, 谷口雄司, 他.75 歳以上高齢者肺癌 の手術成績と合併症 .日胸 .1995;54:19-22.

2. 北村一雄, 大畑正昭, 大森一光, 他 . 高齢者肺癌手術症例 の検討 . 日胸 . 1995;54:458-462.

3. 竹本直明, 松田成人, 浜崎尚文, 他 . 高齢者肺癌手術症例 の検討 . 日胸 . 1995;54:718-723.

4. 前原孝光, 石和直樹, 石橋 信, 他. 75 歳以上高齢者肺 癌切除例の検討 . 日呼外会誌. 1999;13:718-724.

5. 木村文平, 城所達士, 橋爪満, 他.75歳以上の肺癌症 例の手術成績の検討 . 日胸 . 1999;58:790-795.

6 . 坂口浩三, 池田晋悟 , 川野亮二, 他 . 高齢者 (75 歳以上) 肺癌手術症例の検討．日気道会報．2000;5:102-108.

7 . 蒔本好史, 川原克信, 白石武史, 他 . 超高齢者肺癌に対す る外科療法の検討 . 肺癌 . 2000;40:261-265. 
8.最相晋輔，中田昌男，澤田茂樹，他 . 高齢者肺癌切除症例 の検討 . 日呼外会誌 . 2004;18:103-107.

9 . 清水淳三, 渡辺洋宇, 吉田正之, 他 . 高齢者 $(75$ 歳以上) 肺癌に対する肺癌切除症例の検討 . 日呼外会誌 . 1989;3: 329-333.

10. 小玉 仁,吉田一郎,石川 進 ,他 .高齢者肺癌に対する 術式の検討 . 胸部外科 . 1993;46:745-750.

11. 横山秀樹, 一瀬幸人. 高齢者肺癌の手術適応 .肺癌の臨床 . 1998;1:505-509.

12. 並河尚二, 谷一浩, 木村 誠, 他. 75 歳以上高齢者肺 癌の外科治療 . 日呼外会誌. 1989;3:2-9.

13. 綾部公懿, 岡 忠之, 过 博治, 他. 高齢者肺癌縮小手術 症例の検討 . 肺癌 . 1992;32:537-542.

14 . Ishida T, Yokoyama H, Kaneko S, et al. Long-term results of operation for non-small cell lung cancer in the elderly. Ann Thorac Surg. 1990;50:919-922.
15.肺癌の術前術後併用療法. Evidence-based Medicine (EBM) の手法による肺癌の診療ガイドライン策定に関 する研究班 編集. 肺癌診療ガイドライン 2003 年度版 . 東京 : 金原出版 ; 2003:87-89.

16. Kato $\mathrm{H}$, Ichinose $\mathrm{Y}$, Ohta $\mathrm{M}$, et al. A randomized trial of adjuvant chemotherapy with uracil-tegafur for adenocarcinoma of the lung. N Engl J Med. 2004;350:1713-1721.

17 . Strauss GM, Herndon J , Maddaus MA, et al. Randomized clinical trial of adjuvant chemotherapy with paclitaxel and carboplatin following resection in stage IB non-small cell lung cancer (NSCLC): Report of Cancer and Leukemia Group B (CALGB) Protocol 9633. J Clin Oncol. 2004; 22 (Suppl): 7019.

18. Koizumi K, Haraguchi S, Hirata T, et al. Video-Assisted Lobectomy in Elderly Lung Cancer Patients. J pn J Thorac Cardi ovasc Surg. 2002;50:15-22. 